\title{
The Fulfilment of South Africa's Environmental Right: Sustainable Development the Fundamental Building Block
}

\section{Prof CM van der Bank}

\author{
Vaal University of Technology, South Africa \\ Email: riana@vut.ac.za
}

\section{Doi:10.5901/mjss.2014.v5n25p28}

\begin{abstract}
One of the greatest challenges facing South Africa and the rest of the world is to improve the quality of human life for both the present and future generations through sustainable development. The Constitution provides a historic bridge between the past of a deeply divided society characterised by conflict and democracy. South Africa is embracing, at least in theory, the balancing exercise inherent in the quest for sustainability. The principle of sustainability of the environment encompasses the notion of inter-generational equity, that is, the harm to the environment affects the present as well as future generations, what we can call as the tragedy of the commons. Hence, the public needs to be properly and effectively informed regarding any threats to the environment, whether globally, regionally, nationally or locally. Environmental rights mean access to the unspoiled natural resources that enable survival, including land, shelter, food, water and air. Environments rights may be degraded through air and water pollution, noise, ecosystem deterioration and reduced biological diversity. An emerging category of 'environmental rights' requires governments to set environmental standards in order to protect people's surroundings. An unhealthy environment inevitably impacts on the health of the people living with it. Environmental openness is an inalienable human right. The interests of the moment and the importance of a particular development for a particular entity may, however, still dictate the interpretation or lack of interpretation of the balancing of interests. Sustainability is embedded in governance. An attempt to conceal any information about harmful impact on people and the environment is a crime against humanity.
\end{abstract}

Keywords: Environment, Humanity, Social Factors and Sustainability Development

\section{Introduction}

The way the socio-economic rights are framed in the Bill of Rights suggests that they should not be regarded as commodities to be dispensed by the State, free of charge to a pssive citizenry. The destruction of traditional values has effected ethical decision making of most policy makers in poor countries in favour of capitalistic values of individualism and satisfaction (Olanya, 2013). Man has played a very important part in shaping his environment. He has been responsible for degrading the quality of his environment ever since he appeared on this earth. With reference to environmental problems in South Africa, we can point out that population, human settlement, transportation, mining, energy, resources and developments are some important parameters that have bearing directly and indirectly on the environmental policy of South Africa. A new paradigm is emerging to combine law and science for environmental protection and management which provides a new global perspective (Kashyap and Kashyap, 2013). Ecology and international law provide us today with a new mechanism to shape global environments. This combination is likely to evolve sustainable development.

Since 1994, the South African government has taken giant leaps on the path of sustainable development, focusing mainly on correcting the disparities of the apartheid era and building a better future for all the people of South Africa. The strategic framework provides the basis for a long-term process of integrating sustainability as a key component of the development discourse and shows South Africa's commitment to the principles developed at international summits and conferences in the economic, social and environmental fields, including the 2002 World Summit on Sustainable Development (2002 World Summit on Sustainable Development).

Sustainable development is a worldwide aim and on the agenda of many countries; especially the developing and lest developed, such as most countries in Africa. Framework environmental legislation plays an integral role in fulfilling the overall mission of assisting countries to build capacity for development and the implementation and enforcement of environmental laws, and strengthens environmental institutions for sustainable development and poverty reductions.

One of the main aims of the African Renaissance is to mobilise the people of Africa. Development must be socially, environmentally and economically sustainable. Environmental justice must be considered before a developmental can 
proceed and there should be equitable access to environmental resources, benefits and services to meet basic human needs. Over the years, Africa has received foreign assistance, but the Renaissance inspires all Africans to take their destiny into their own hands. South Africa's technological, communication and education capabilities should be used to transfer knowledge and skills through awareness campaigns to the most remote places. In the process, all stakeholders, no matter who and where they are, should develop an awareness of the objectives of the African Renaissance. Once informed, these leaders, institutions and individuals should be in a position to identify, accept and understand the dilemma they are confronted with. Being empowered with knowledge, they should then be in a position to organise themselves or empower groupings to exert pressure on the sources of power to institute change on their behalf (Louw, 2000).

\section{Sustainable Development}

One of the most influential definitions of the term "sustainable development" is that of the Report of the World Commission on Environment and Development: Our Common Future (WCED), widely known as the Brundtland Report."Sustainable development" is defined in the Brundtland Report as: "Development that meets the needs of the present without compromising the ability of future generations to meet their own needs" (WCED, 1987).

Another definition that can be given to sustainable development is to perform activities that safely can be performed indefinitely. This supposes that the activities will be performed in the environment, and that it will be possible to continue to perform these activities in the environment indefinitely. Sustainable development should in other words be understood in two contexts, the first having to do with people's needs and the second dealing with the technology and social organisation which will ensure the environment's ability to meet the needs of present and future generations. The findings of the Brundtland Report include the recommendation that the environment should be re-examined in the context of developmental issues (WCED, 1987).

In the broader context the Brundtland Report suggests that the impact of development on the natural environment should be established and that a limit should be put on further development in order to ensure that the environment is able to sustain the survival of future generations. The Millennium Ecosystem Assessment claimed that human activity is putting a strain on the environment and the natural ecosystem and that such sustainability can therefore no longer be taken for granted. Human economic, social and environmental systems are inextricably linked, and their development should be controlled and monitored simultaneously. These systems are referred to as the three pillars of sustainable development (Kidd, 2011).

The International Council for Local Environmental Initiatives (ICLEI) emphasises environmental, social and economic concerns as three distinct, but interrelated, components of sustainable developments. Sustainable development is a programme to change the process of economic development so that it ensures a basic quality of life for all people, and protects the ecosystems and community systems that make life possible and worthwhile (Van der Merwe \& Van der Merwe, 1999).

There are three interrelated elements in most of the definitions. Firstly, the core objective of sustainable development is optimising human welfare. Human welfare refers to the general well being of someone. It covers aspects ranging from good fortune, health, happiness, education, equality, prosperity, among others. It is a term commonly associated with the principle of common good which include the opportunity of human rights. The second objective is that all physical and economic activity should be compatible with the surrounding biosphere. This element focuses on nonrenewable resources, and emphasises that these resources should not be used at a rate that exceeds the rate at which they can be substituted by renewable resources. The third element is the equitable distribution of bio-spherically compatible improvements in human well-being, both today and tomorrow. Sustainability in this context, implies both intergenerational equity and intra-generational equity.

Sustainable development has a strong focus on responsible use for resources and so has the notion of "green building" and "green design". The relevance of "green building" with its focus on the limitation of resource use and environmental harm comes to the fore also in Kotzé's view of sustainability as being "the ability to maintain a desired condition over time without eroding natural, social and financial resource bases, through a process of continual improvement in the form of sustainability. Sustainability also relates to the integration of various considerations, including: the environment, the economy, social factors, environmental governance and management efforts, and public and industry involvement. Sustainable results may be achieved through the application and implementation of various principles of sustainability and continual monitoring and post-decision follow-up of the results of these efforts (Kotzé, 2000). Viewed against the definition in the Brundtland Report, Kotzé's description of sustainability includes the notion, as do "green building" and "green design", that the natural environment must be maintained in a certain desired condition. 


\section{The Environment and Sustainable Development}

Environmental conditions relate to three key dimensions of poverty: (1) Livelihoods: Poor people tend to be most directly dependent on natural resources, and are therefore the first to suffer when these resources are degraded; (2) Health: Poor people suffer most when water and air are polluted because pollution sources are often placed in or near poor communities; and (3) Vulnerability: Poor people are most often exposed to environmental hazards and environmentrelated conflict, and are least capable of coping when they occur. While wealthier people are able to afford medical care for pollution related sicknesses like asthma and are able to move out of congested and polluted areas, poor people cannot.

\subsection{The Legacy of Apartheid}

The brutal features of apartheid - forced removals to less productive and less desirable areas, overcrowding in the socalled 'homelands', discriminatory policies affecting blacks who live in or near cities, and the migratory labour system alienated people from their land and resources and contributed to inequitable access to environmental services, unjust land-use policies and environmental degradation. Under the homelands system, blacks would no longer be citizens of South Africa, becoming citizens of the independent homelands who worked in South Africa as foreign migrant labourers on temporary work permits. In 1958 the Promotion of Black Self-Government Act was passed, and border industries and the Bantu Investment Corporation were established to promote economic development and the provision of employment in or near the homelands. Many black South Africans who had never resided in their identified homeland were forcibly removed from the cities to the homelands. Apartheid economic development was based on an unsustainable dependence on extractive activities, and cheap electricity from dirty power like coal and oil. This has left a legacy of unsustainable development and environmental havoc. Agricultural production has been resource intensive and environmentally degrading as a result of various government policies. For example, the government has chosen to subsidise damaging pesticides instead of promoting natural methods of pest control. The wrong subsidies result in the loss of biodiversity and the inefficient use of scarce resources.

\subsection{Environmental Service Delivery}

The main goals are to promote constitutionally grounded environmental jurisprudence and to enforce the environmental rights of marginalised groups in South Africa. The delivery of environmental services is a fundamental goal to all citizens of sustainable development. Adequate environmental services have in the past been denied to blacks living in both urban and rural communities. Environmental services like access to safe drinking water, proper sanitation, adequate housing, electricity and effective waste removal not only diminishes health and environmental risks but also contributes in many ways to economic development. Service delivery has suffered in part due to shortcomings in involving stakeholders directly in the process of designing service delivery programmes. (South African Human Development Report 2003).

There are serious resource constraints in South Africa. Fresh water, clean air, fish stocks, and food production and living space are all under pressure because of the country population's increasing consumption and pollution. South Africa has many examples of problems we face to make development sustainable. South Africa are rapidly increasing the access to water and electricity for poor people. As the economy grows there will be increasing pollution and pressure on natural resources. Government has to balance the need for development with the sustainable use of resources.

\subsection{Tourism and Ecotourism}

The Department of Environmental Affairs and Tourism promotes growth in ecotourism, which allows South Africa to make the most of its unique environmental heritage. Thus, preserving a beautiful natural environment benefits the tourism industry and the country as a whole by improving the economy. Tourism in South Africa drives economic growth and job creation. Last year, more than 7 million visitors came to South Africa. South Africa's three declared World Heritage Sites are major tourist attractions that benefit local communities who participate in the resulting economic expansion. Tourism has the greatest potential to create jobs in the South African economy. The Western Cape alone benefits from a large tourism industry. 976,000 overseas tourists, and 396,000 visitors from Africa, visited the Western Cape in 2002. These overseas visitors spent R17.3 billion in 2002 (Grant Thornton Kessel Feinstein, Tourism Fact Sheet, 2002). The tourism industry creates jobs in many areas including hospitality (hotels, restaurants etc.), transportation (airlines, taxis, buses etc.), and retail sales (souvenirs, art etc.). By protecting the environment so that foreigners will want to visit it, the 
government is actually promoting industry and jobs. In this case, the environment and development are not in conflict.

\section{The Role of Legislature in Ensuring Environmental Sustainability in South Africa}

Environmental sustainability has been a poor cousin of economic and social development; however it is further becoming evident that natural resource endownents are central to achieving millennium development goals and economic development that also ensures prioorties such as job crestion are realised. The impact of the degraded ecosystem is that both the water quality and quatity in the river system will be compromised, leading to unreliable and higher costs of providing water services to communities and industries. The development of ecoomic infrastructure such as water, energy, transportation and telecommunications should consider environmental sustainability during the design stage so as not to commit us to unsustainable parths. South Africa must continue to deveop sustainable development into policies and programmes and continious interventions at al three levels namely national, regional and local. Access to legal assistance for poor communities, especially in rural areas, is a major challenge. The State-funded legal aid system, based on the judicare system, is facing serious budgetary constraints. Initiatives are currently underway to reform the system, but in the mantime there is a serious lack of access to legal representation in a range of cases, invcluding those critical to the land reform process.

\subsection{Water availability and quality}

The country have less water than before available, of poorer quality. Essentially, water quality management employs a combination of the four environmental management instruments, viz.: the regulatory, market-based, self-regulatory and civil management instruments.

\subsubsection{Regulatory management instruments}

Water use, and impacts on water quality are regulated through a range of authorisations, which are either being directly managed by the Department of Water Affairs and Forestry, or in co-operation with other government departments, e.g.:

- Licensing of water use that may have, or may potentially have an impact on water quality in terms of Section 40 of the National Water Act, 1998 (Act No. 36 of 1998);

- issuing of disposal site permits in term of Section 20 of the Environment Conservation Act, 1989 (Act No. 73 of 1989);

- recommendation for approval of Environmental Management Programs (EMPs) in terms of Section 39 of the Minerals Act, 1991 (Act No. 50 of 1991) to the Department of Minerals and Energy; and

- recommendation for approval of Environmental Impact Assessments (EIAs) in terms of Sections 21, 26 and 28 of the Environment Conservation Act, 1989 (Act No. 73 of 1989) to the Department of Environmental Affairs and Tourism.

\subsubsection{Market-based management instruments}

Water quality management the (Pricing Strategy), which includes a system of waste discharge charges, makes provision for certain incentives which has as its aim-

- the introduction of new technologies or management practices;

- the conservation and the economically efficient allocation of scarce water resources;

the removal of elements of waste streams

\subsubsection{Self-regulatory management instruments}

The ISO 14000 series of environmental standards provides a range of self-regulatory management instruments, which can be utilised by industry to improve their environmental performance. The only component of the ISO 14000 series of environmental standards that is required for certification at the moment, is ISO 14001. Before an organisation can obtain ISO 14001 certification, it must, amongst others, have considered all legal requirements. In promoting ISO 14001 certification, the Department of Water Affairs and Forestry will be able to extend its water quality management capacity. 


\subsubsection{Civil management instruments}

The National Water Act, 1998 (Act No. 36 of 1998) requires where appropriate, the delegation of management functions to a regional or catchment level so as to enable everyone to participate. The importance of public participation is further emphasised by the National Environmental Management Act, 1998 (Act 108 of 108) which lays down the principle of transparent and participative management for co-operative environmental management. A consequence of this decentralisation of decision-making requires the establishment of catchment based institutions such as Water User Associations and Catchment Management Agencies to ensure public participation. Within water quality management, catchment forums have provided an ideal mechanism to facilitate the involvement of stakeholders in decisions affecting their water quality. Catchment forums serve as suitable platforms for efficient and coherent participation of stakeholders with diverse interest.

\subsection{Allocation strategies}

Economists believe that water in industrial use can create more jobs than water in agriculture - yet there are significant questions regarding the sustainability of both urban and rural economies if water is too rapidly moved from the agricultural sector to the industrial sector.

South Africa is also a country that already has a significant number of inter-basin transfers. Water is piped from a number of catchments. And even from foreign countries to areas of high demand and inadequate supplies, such as the Reef area. This is a very complex situation and the Department of Water Affairs and Forestry will have to continue to make decisions regarding the future allocations of water through inter-basin transfers. Different regulations will be applied for different countries. This raises important questions for example of how much water is actually available and the socioeconomic question of where it will be most beneficially used in the public interest. The potential exists then for management of water scarcity to become a tool for the exclusion of the previously disadvantaged and the poor from access to water and from the right to use water for economic development to escape the poverty trap.

The National Water Act specifically requires consideration of redressing of the discrimination of the past, on the basis of both race and gender, in the allocation of water. This need has to be balanced by the need for improved efficiency of use as we try to manage our increasing water scarcity.

\subsection{Protecting Water Resources}

South Africa need to incorporate the protecting of water resources in their planning, which are critical to food security. In the coming years, water for agricultural consumption will be stretched to a large extend. The availability of water could decline by more than 10 percent. Climate change threatens biodiversity and ecosystems, which are the foundation of agriculture. The development of economic infrastructure such as water should consider environmental sustainability during the design stage so as not to commit us to unsustainable paths. The opportunity therefore lies in long term economic planning and recognising that the ability to achieve global environmental sustainability is intricately linked to how we cooperate as countries of the world. Regional initiatives such as on transfrontier parks, shared water course management and regional utilities further provide an opportunity for achieving these sustainable objectives and goals. Impressive innovation and smart government policies are changing age old farming ways. Some of the countries in Africa have already begun their agricultural revolutions. These successions must be extended to the rest of Africa.

South Africa must continue to integrate the principles of sustainable development into policies and programmes and requires continuous interventions at international, regional, national and local levels.

\section{Climate Change - Threats and Affects}

South Africa is particularly vulnerable to climate change because, among other issues:

- A large proportion of our population has low resilience to extreme climate events (poverty; high disease burden; inadequate housing infrastructure and location);

- Large parts of South Africa already have low and variable rainfall;

- A significant proportion of our surface water resources are already fully allocated;

- Agriculture and fisheries are important for food security and local livelihoods.

Although the poor are only minor contributors to climate change, they are the most vulnerable and, hence, will be 
the most impacted. The rest of Africa is possibly even worse off.

Cross-cutting global trends will have very specific impacts on our shorter-term social and economic policies that include climate change. Climate change already contributes to the problem of disease and premature deaths worldwide, and this is projected to become worse over time especially in low-income countries. In particular, the IPCC found with high confidence that there will be an increasing number of people suffering death, injury and disease from heatwaves, floods, storms, fires and droughts.

Heart and lung illnesses will most likely increase as ground-level ozone (a toxic gas), smoke and airborne dust increase in response to warmer temperatures. Higher temperatures may also lead to the spread of malaria across densely populated parts of Zimbabwe and also onto the South Africa highveld. Dengue fever, also carried by mosquitoes, may also spread into areas of southern Africa where it previously did not occur.

Aside from the direct impacts of floods on human health, such as drowning, there are other flood-related impacts such as the outbreak of diarrhoea as water supplies become contaminated.

Some impacts of climate change on human health are mentioned under the question above relating to food security; diminished food availability, food access and nutrient content and will result in more malnutrition and starvation.

Global change must be provided sensitivity and vulnerability information at regional and municipal levels. Consolidating the latest findings on global and local change impacts on various key sectors such as agriculture, socioeconomics, water and biodiversity and the coastal zone. Provides an overview of a wide range of aspects with regard to the impact of climate change in the Southern African region.

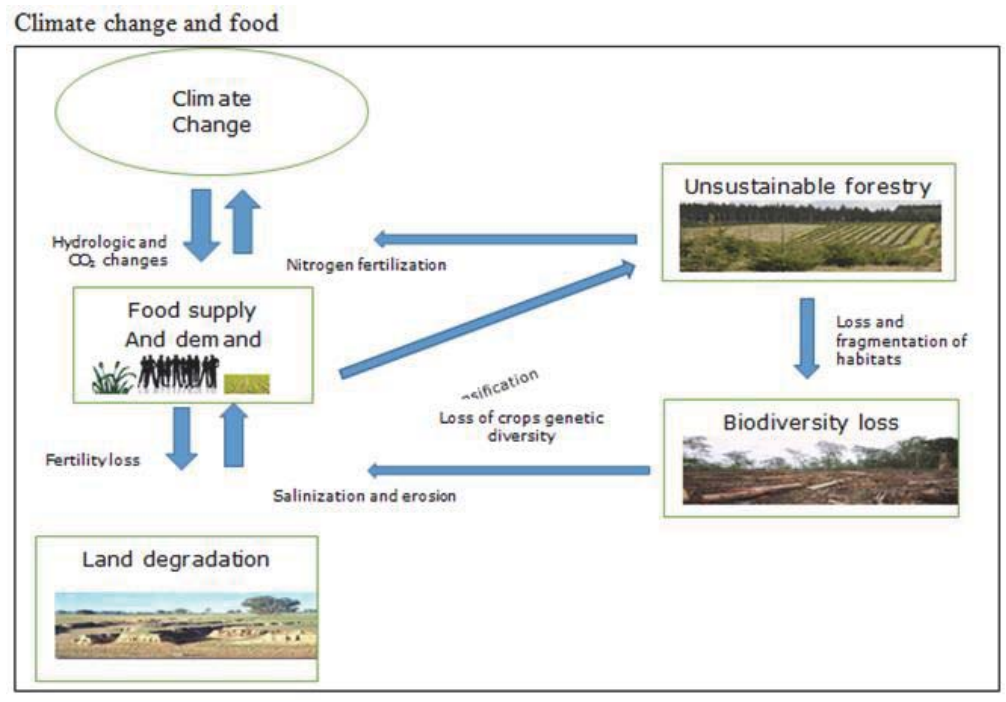

\section{Cooperative Government and Public Administration}

The weighing of sustainability factors by authorities often necessitates co-operative governance and good intergovernmental relations (Bray; 2008).Chapter 3 of the Constitution is devoted to co-operative government and compels the three spheres of government in South Africa inter alia to secure the wellbeing of the people of the Republic; to provide effective, transparent, accountable and coherent government for the Republic as a whole; to respect the constitutional status, institutions, powers and functions of government in the other spheres (Section 41 of the Constitution, 1996).Cooperative government is very important in an environmental law setting, as matters pertaining to the environment are regulated by several government departments. The Intergovernmental Relations Framework Act 13 of 2005 were adopted to establishes a framework for the national, provincial and local spheres of government to promote and facilitate intergovernmental relations and to provide mechanisms and procedures to facilitate the settlement of turf wars between national and government departments.

Section 41(1)(h), 154(1) and 155(6)(a) of the Constitution placed significant emphasis on the idea that national, provincial and local authorities should support one another, but a system of intergovernmental checks and balances is provided for to extent that provision for national intervention in provincial administration and provincial intervention in local government. With checks and balances, each of the three branches of government can limit the powers of the others. This way, no one branch becomes too powerful. Each branch "checks" the power of the other branches to make sure that 
the power is balanced between them. National government seemed hesitant to interfere in provincial matters except politically, because some of the premiers of provinces and members of executive committees have been replaced long before the expiry of their office. At national and provincial levels changes were made to some of the departments with an environmental mandate. IN North West province the environmental section was moved from agriculture and conservation to economic affairs and tourism (North West Provincial Government). In some of the Provinces the environmental section forms part of the department responsible for economic affairs.

\section{Sustainability Mechanisms in the Environmental Sector}

National Environmental Management Act 107 of 1998 (NEMA) is South Africa's environmental framework law where sustainability development principles were included.

The sustainable development principles of the NEMA reflect the idea of the balancing of interests. Section 2(2) states: "Environmental management must place people and their needs at the forefront of its concern, and serve their physical, psychological, developmental, cultural and social interest equitably."

Environmental implementation plans must be prepared by government departments in terms of chapter 3 of NEMA. The plans must reflect the balancing of all sustainability interests. NEMA provides for dispute resolution mechanisms such as conciliation, arbitration and investigation. No specific mention is made of the balancing of interests of different parties but due to the nature of conciliation and arbitration and the framework within which the conciliator and arbitrator will have to function in terms of the NEMA, one may deduce that social, economic and environmental factors should be taken into consideration.

NEMA also includes the duty of care and the polluter pays principle in section 28. Pollution was also criminilised in 2009. No person may unlawfully and intentionally or negligently commit any act or omission which causes significant or is likely to cause significant pollution or degradation of the environment.

Section 32 of NEMA includes instruments available to civil society. Private persons may institute private prosecutions in the public interest or in the interest of protecting the environment. Agreements may be concluded by a private person, relevant ministers or members of executive committees of provinces as well as communities. The agreement could be used for example to improve the standards or commitments of the person in terms of the law, or to commit itself to reaching the set targets within a certain time period and to providing for independent monitoring. The agreement must be preceded by a public participation process .Balancing of interests of the person, community and the environment may still take place.

\section{Conclusion}

It seems that government provides for the consideration of environmental, economic and social factors in its decisionmaking and planning. In the balancing of the various sustainability factors, the decision-maker may emphasise one or the other factor to a greater or lesser extent depending of the purpose of the legislation and the objectives of the line functionary. However, if the legislation is to be read with section 2 principles of NEMA, the sustainability criteria should be in balance. If one of the criteria is skewed, then the possibility exists that sustainability would fail. The balance might be easier described than achieved. When an issuing authority has to deal with the approval of an authorisation, he or she may be persuaded to make such decision as to give effect to the immediate developmental goals of government. In such cases, the decision-maker is placed in a very difficult position.

The challenge of achieving sustainability is "compounded by the grave long-term risk that climate change poses" (Mwebaza and Kotze; 2009). Climate change and natural disasters increase the need for cooperation and integration in areas of economic policy, infrastructure, interdisciplinary research and the management of transboundary natural resources. Climate change is increasingly likely to compel the public and private sectors in South Africa and balance the factors necessary for sustainability. It is not possible to combat human and ecological vulnerability without having access to infrastructure, financial resources and food security mostly dependent on economic and agricultural activity, all of which have an environmental footprint. Government admits to the key role that sustainability development has to play in addressing the causes and impacts of climate change.

The National Water Act is a very ambitious Act aimed at achieving effective, sustainable management of South Africa's water resources in order to ensure not only all people have sufficient access to this scarce resource but also that there is enough water available to meet environmental needs (Kidd; 2011).

South Africa has a challenging task in meeting the twin needs of economic and social development as well as sustainable environmental management simultaneously.Public participation in environmental decision-making, however, 
will be ineffective unless people have access to the information necessary for their role to be meaningful. The Constitution assist in this regard.

The effectiveness of the enforcement of South Africa's environmental laws has been a concern for years and there is still concern in this regard. There are now more mechanisms for enforcement than ever before, and encouraging developments in the enforcement and compliance arena, but there is still considerable room for improvement (Kidd; 2011).

\section{References}

Journal of Environmental Law and Policy 2008.

North West Provincial Government website http://www.nwpg.gov.za (accessed 28 May 2014)

Kashyap A and Kashyap SB Environmental protection vis-à-vis sustainable development - global challenge, OIDA International Journal of Sustainable Development 06, vol 12, 2013. pp1-15.

Kidd M Environmental Law 2nd Juta Cape Town 2011.

Louw , AH The concept of the African Renaissance as a force multiplier to enhance lasting peace and stability in Sub-Saharan Africa, Research Paper, Executive National Security Programme 02/2000, South African National Defence College, 17 October 2000.

Mwebaza, R and Kotze, LJ Environmental governance and climate change in South Africa: Legal perspectives, 2009.

Olnaya D.R. African Environmental values and Climatic change OIDA International Journal of Sustainable Development Vol 6 no 4 pp115-128 2013.

Fitzmaurice M, Ong DM and Merkouris P Research Handbook on International Environmental Law, Edward Elgar Publishing Limited UK 2010.

Kotzé LJ A Legal Framework for Integrated Environmental Governance in South Africa and the North-West Province (LLD Thesis NorthWest University 2006).

Van der Merwe, I. \& Van der Merwe, J. 1999. Sustainable Development at the local level: An Introduction to Local Agenda 21 - A South African version. Department of Environmental Affairs and Tourism. South Africa.

World Commission on Environment and Development: Our Common Future (WCED), widely known as the Brundtland Report, 1987.

\section{Legislation}

Constitution 1996

Intergovernmental Relations Framework Act 13 of 2005

National Water Act 36 of 1998.

National Environmental Management Act 107 van 1998 